Bulletin of the School of Oriental and African

Studies

http://journals.cambridge.org/BSO

Additional services for Bulletin of the School of Oriental and African

Studies:

Email alerts: $\underline{\text { Click here }}$

Subscriptions: $\underline{\text { Click here }}$

Commercial reprints: $\underline{\text { Click here }}$

Terms of use : $\underline{\text { Click here }}$

\title{
NADIA EBOO JAMAL: Surviving the Mongols: Nizari Quhistani and the continuity of Ismaili tradition in Persia. (The Institute of Ismaili Studies, Ismaili Heritage Series, 8.) xvi, 190 pp. London: I. B. Tauris, 2002. £25.
}

\section{GEORGE LANE}

Bulletin of the School of Oriental and African

Studies / Volume 66 / Issue 02 / June 2003, pp 268 - 270

DOI: 10.1017/S0041977X0336015X, Published online: 04 September 2003

Link to this article: http://journals.cambridge.org/abstract_S0041977X0336015X

How to cite this article:

GEORGE LANE (2003). Bulletin of the School of Oriental and African Studies, 66, pp 268-270 doi:10.1017/ S0041977X0336015X

Request Permissions : $\underline{\text { Click here }}$ 
and translations, but I must reiterate that even with this help the texts present difficulties which, while not insurmountable, are considerable.

Khan tells us that the legend of the conversion of the Qaraqosh to Christianity by John of Daylam derives from a monophysite source. Catholicism was brought to them in the middle of the eighteenth century. Most of the Qaraqosh work in agriculture and usually possess some land. The introduction to this work offers us a most helpful survey of the lives of the Qaraqosh and their language.

The present book-even without taking into account the others written by Khan over recent years - is a massive achievement, and I look upon his study of the Qaraqosh dialect with genuine awe. I cannot readily think of anyone else who has produced so much in so little time to such magnificent effect. Geoffrey Khan can now well afford to rest on his laurels for quite a while.

EDWARD ULLENDORFF

NADIA EBOO JAMAL:

Surviving the Mongols: Nizārī Quhistān̄ and the continuity of Ismaili tradition in Persia.

(The Institute of Ismaili Studies, Ismaili Heritage Series, 8.) xvi, 190 pp. London: I. B. Tauris, 2002. £25.

The fate of the Persian Ismailis after their uprooting and devastation by Hülegü Khan in the thirteenth century is a subject deserving of further research and attention. Even though a well regarded Ismaili poet lived and worked during this tumultuous period, before Nadia Eboo Jamal's book few detailed studies on this subject have been published in English. Her book therefore sheds a welcome light on the Il-Khanate in general, and the Persian Ismailis and Nizārī Quhistānī (1247-1320) in particular. Nizārī’s poems have not previously appeared in English translation, and very little on his life and background has been published in the West. Surviving the Mongols contains many translated quotations from Nizārî̀'s work and recounts the main details of his life, placing them in the political and social context of his time. Nizārî̀s life and work are considered in relation to his Ismaili beliefs, his links with the Ismaili community and Sufism and also the reaction of his patrons and friends to these so often despised beliefs.

The Nizārī Ismailis of Persia developed a distinct identity and tradition during the Alamut period in Iran, from 1090 until their near-extinction in 1256. Their leaders and imams, from Hasan-i Sabbah to Rukn al-Dīn Khurshāh, cultivated a courtly environment of pious erudition, science and discourse and the Ismaili mountain retreats became known as havens of knowledge and learning. Not all who sought sanctuary in their isolated strongholds were true believers but, rather, were drawn to the secretive sect by the reputation of the Ismaili libraries and scholars. The Ismaili imam resided in the seemingly impregnable fortress of Alamut, high in the Elborz Mountains north of Qazvin. The poet Nizārī was born in Birjand in the region of Quhistan, today the border district of eastern Iran and western Afghanistan. The province of Quhistan held a number of Ismaili fortresses and Birjand was a commercial city with a large Ismaili population. In 1253-54 Quhistan was hit by the first wave of Mongol assaults against its Ismaili residents; Nizārî̀'s family survived with their lives-possibly because they lived outside the city - though not with their lands. Forced to seek employment 
away from his family, Nizārī worked first for the Mongol governor of Quhistan but eventually ended up in Herat working for the Kart administration as a tax collector, a role which involved a certain amount of travel. In 1280 he travelled extensively in the Caucasus and Azerbaijan in the retinue of the Săhib Dīwān, Shams al-Dīn Juwaynī, though it is difficult to ascertain in what capacity Nizārī was included in the party. After his travels, which appear to have been a cover for him to visit the scattered Persian Ismaili community, the poet resigned his post in Herat and returned to Birjand to write poetry. During this period he was employed as a court poet for a local ruler, the Mihrabānid Shams al-Dīn 'Alī Shāh.

Nizārī Quhistān̄̄ lived during turbulent times and his life and work could shed light on many aspects of this period that are still obscure and unclear. For this reason alone Eboo Jamal's book must be welcomed. However, she has failed fully to explore the implications of the events of his life by accepting too readily now outdated views and interpretations of the early Mongol period. It has now been generally recognized that Iran's experience of the Mongols falls into two distinct phases, and that the Il-Khanid years cannot be equated with the chaos which existed after the initial invasions of $c .1222$. Unfortunately Eboo Jamal employs the same tired clichés and rounds up the usual suspect quotes to describe both periods. Ibn al-Athir is quoted to encapsulate the 'cataclysmic events' with Hülegü seen as just another Mongol conqueror continuing the mayhem of his grandfather (p.69). With such a wealth of new material to work with it is regrettable that this book has not adopted a more recent scholarly backdrop against which to set the life, thoughts and work of Nizārī Quhistānī.

This shortcoming is compounded by an over-reliance on secondary sources, surprising given the abundance of available primary source material from the Il-Khanid period. Howorth, Hodgson, Bosworth, Boyle, Petrushevsky, Ivanhow, and of course Daftary are all called upon and relied upon not only for their interpretations and worthy insights but sometimes even for citations, quotations and facts readily available from more contemporary sources (pp. 71-3). Petrushevsky is even cited for anecdotes related by Nizārī himself. Two Central Asian scholars, Chengiz Baiburdi and Chingiz Baradin, not only provide Eboo Jamal with much of her factual information on Nizārī but also with citations and references to Nizārī's written material (pp. 62, 65) though the author does acknowledge this debt to Baiburdi. A result possibly of this reliance on secondary sources are factual errors. The historian and statesman 'Atā' Malik Juwaynī died, vindicated and of natural causes, in 1283 . He was not executed in 1280 as stated on p. 136. Though the Shirazi poet Hāfiz played ambiguously with images of wine and lovers, Jalāl al-Dīn Rūmì did not (p. 128). Shams-i Tabrīzī, Rūmī's spiritual mentor, was a scholar of high standing and not just a 'wandering darwish' (p. 132), he died in 1247 not 1257 (p. 134) and the erroneous claim that he was born into an Ismaili family is not substantiated or referenced (p. 133).

One of Eboo Jamal's stated aims in Surviving the Mongols is the exploration of links and influences between Nizārī and Sufism. The shrouding of Ismailism under the cloak of Sufism was a convenient method of taqiyya. The language of Sufism was also pervasive in most Persian poetry of the time and Sufi imagery, combined with Shia ideological references, provided an obvious format and possible disguise for Ismaili propoganda. Eboo Jamal clearly demonstrates how this link developed at this time rather than later as has been commonly assumed. Her treatment of Nizārī's Safa-nāma as an account of the author's secret visit to the sites of Ismaili activity in Mongol 
Iran is convincing. However, the reasons for the extreme antipathy towards the Ismailis at this time are not explored and the author's sympathy for the Ismaili cause is sometimes too apparent.

Though Nadia Eboo Jamal's book is a most welcome contribution to the study of the earlier Il-Khanate, it raises more questions than it answers. Some answers must remain conjecture at this point due to the evasive and secretive nature of the source material, a point readily conceded by Nadia Eboo Jamal, but it must be hoped that this book will inspire further research into this period in general and into the shrouded activities of the Ismailis during the Mongol decades in particular.

GEORGE LANE

\author{
MICHAEL E. STONE, DICKRAN KOUYMJIAN and HENNING LEHMANN: \\ Album of Armenian paleography. \\ 554 pp. Aarhus: Aarhus University Press, 2002. $£ 126.75$.
}

The publication of this sumptuous volume is a major event in Armenian studies. This is the first book on Armenian palaeography written in any Western language, and the collection of nearly 200 full colour plates of dated Armenian manuscripts from the ninth to the nineteenth centuries is unlikely ever to be surpassed. The album provides an excellent overview of all the different forms of the Armenian script, and the use of computer scanning and imaging has enabled the creation of tables of comparative letter forms, which allow the reader to trace developments in the script over the last 1600 years.

The saint Mesrop Maštoc' (to whose memory this book is dedicated) is reputed to have invented the Armenian alphabet at the beginning of the fifth century, and it has been a source of national pride and a symbol of Armenian identity ever since. The Armenians' reverence for the written script may account for the fact that they continued to commission manuscript versions of texts long after the invention of the printing press and the publication of the first Armenian books. The album includes plates of fine illuminated manuscripts from as late as the eighteenth and nineteenth centuries. Armenian scribes and patrons were also reluctant to depart from the traditional appearance of the script, with the result that it is not easy to date a text accurately from palaeographical information alone. The primary aim of the album is consequently to gather together representative dated manuscripts in order to assist scholars to recognize the subtle changes in the script from generation to generation, and to provide comparanda for other undated manuscripts. The manuscripts reproduced in the album come principally from the large collections in Yerevan, Jerusalem and Venice, but a number of texts from smaller collections are included, some of which would otherwise be difficult to access (note the two plates devoted to copies of the Gospels kept in Curlut' Village, Axalc'a, Georgia, numbers 8 and 9). Accompanying each plate there is a description of the manuscript, and information on its scribe, provenance and the patron who commissioned the text (where known), and a computer scan of every single letter. There is also a transcription of a representative sample of each manuscript. The transcription is perhaps the least satisfactory part of the volume, since the editors have sometimes missed off indications of supralinear strokes or accent-marks and punctuation, and have not reproduced the word spaces used in the original (this is sometimes of considerable interest, note for example the Gospel texts 108 and 133 which 